\title{
Quality In E-Procurement Success
}

\author{
Mahnaz Eskandarian, Department of Management, Payame Noor University, Tehran, Iran \\ Govindan Marthandan, Ph.D., Multimedia University, Malaysia \\ C. A. Malarvizhi, Ph.D., Multimedia University, Malaysia \\ Sanaz Zolfaghar Tehrani, Multimedia University, Malaysia
}

\begin{abstract}
Nowadays, the quality of virtual service is diminishing, in which different aspects of E-business industry is signifying, especially in the business to business $(B 2 B)$. E-procurement is part of the e-business, therefore, quality factors of E-procurement originates from e-business. Much research has focused on the critical success factors of Eprocurement, however, when it comes to implementation, many E-procurements fail, which can be very costly. This article attempts to increase the success rate of E-procurement, and ensures that the success of E-procurement is more sustainable. This research estimates the structural equation model by collecting data from 208 managers to employ quantitative analysis to investigate the relationship between E-procurement quality factors. The result of this research shows that the quality of the organization culture has partial mediator relationship to the success of Eprocurement. Meanwhile, the quality of IT infrastructure does not have a mediator relationship with the succes s of E-procurement. Lastly, quality of knowledge management has a full mediator relationship with the success of Eprocurement and it does not affect the dynamic capability oforganization directly.
\end{abstract}

Keywords: E-Procurement; B2B Quality; E- Business; Service Quality; Dynamic Capabilities Theory

\section{INTRODUCTION}

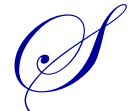

upply-Chain Management (SCM) develops through the successful process flow of procurement, in which the flow of the overall chains is a crucial factor that can affect the whole chain performance. Besides, "Internet Revolution" in 1990s has sparked the emergence of WWW (World Wide Web), ERP (Enterprise Resource Planning), SCM, and electronic technology; these have been responsible in pushing businesses to venture across borders through e-business. Under those circumstances, the quality of the job and the answers to the questions of "which" and "how" business process model will be utilised for implementing E-procurement, become very important. With due attention given to all E-procurement business models, most of the supply chains fail because of low quality E-procurement, which cannot achieve the pre-defined goals and targets (Kothari, Hu, \& Roehl, 2005).

This research relates to the aspect of quality as it helps the supply chain to attain a higher success rate of Eprocurement strategic goals. Service quality models such as the SERVQUAL and INDSERV are the most common models used to study the total quality management in B2B and purchasing quality to analyse the gaps between the perceived and the real quality perspectives. Moreover, the roles of IT and the theory of Dynamic Capability are integrated by the supply chain system, which explain the success of E-procurement. SCM is the most effective means which can potentially bring competitive advantage into organizations (Lattimore, 2001). It is also a tool which plays a critical role to achieve customer satisfaction (Mentzer et al., 2001). In the supply chain, information is critical, since it plays a key role in reaching the coordination of all parties involved. Information systems and technologies are potential facilitating tools that could help achieve this coordination/integration, thus enabling the entire supply chain to reach a virtual integration.

This research identifies three main dynamic capabilities for E-procurement adoption and development from the quality perspective, which are: 1) Organization culture and structure; 2) IT infrastructure and technology; and 3) Knowledge management capability. The objective of this paper is to find out how the quality in critical dynamic capability of E-procurement can influence its success and implementation. Therefore, the objectives of this research are: 
1. How does the quality in the organization culture in its E-procurement initiative and capabilities affect the success of E-procurement?

2. How does the quality in IT- infrastructure in its E-procurement initiative and capabilities affect the success of E-procurement?

3. How does the quality in Knowledge Management Capability in its E-procurement initiative and capabilities affect the success of E-procurement?

As for the contribution of this research, firstly, this research applies the Dynamic Capabilities Theory for Eprocurement success and the sustainability of E-procurement service in the supply chain. Therefore, this research identifies the E-procurement capability and dynamic capability, which it shows the applicability of DCT in electronic service and improvement. Secondly, this research combines quality model and operational Theory of DCT to E-procurement success. The INDSERV and B2B quality models introduce the initiative and implementation of quality factors for E-procurement, which is the novelty of this research. Therefore, this research develops the structural equation model for sustainable success of E-procurement. The paper explains about the theoretical support and the analysis of the quality model that determines the success of E-procurement.

\section{Conceptual Framework and Theoretical Support}

The B2B Service quality measurement and conceptualization has different models, in which in the years of 1988, 1991, and 1994, Parasuraman and colleagues used the SERVQUAL scale model (Ashnai, 2006; Burgess, 2014; Goetsch \& Davis, 2014; Gounaris \& Gounaris, 2005; Kajan, 2012; Lee \& Gregory, 2010; Naudé et al., 2007; Rahayu \& Anggriawan, 2014; Segarra-Moliner, Moliner-Tena \& Sánchez-Garcia, 2013; Su, Song, Li, \& Dang, 2008; Sun et al., 2014; Van Aerschot, 2007). Besides, the SERVQUAL scale, B2B service is naturally more sensitive and known to have an initial good and long-term relationships before any development in the quality (Naudé et al., 2007). It is also the reason why the SERVQUAL scale is not admired in the B2B context (Hussein et al., 2015).

Gronroos abstracted the first quality model in a B2B context with two dimensions, functional and technical qualities (Brensinger \& Lambert, 1990). The functional quality is "the process and the interaction during service provision, while the technical quality covers the aspects of service outcome" (Hussein et al., 2015). Afterward, Gronroos established six dimensions "professionalism and competence/ skills, reliability and confidentiality, attitudes and behavior, accessibility and flexibility, error and reputation fixing and credibility" for B2B service quality evaluation (Hussein et al., 2015). Morgan followed the Gronroos dimensions, with the method of service delivery as the process that is obtained from service delivery as a result (Al-Awadhi, 2009). Furthermore, Szmigin proposed a model with three dimensions; hard (process), soft (interaction) and outcome (Ashnai, 2006;Badlani \& Paryani, 2015; Gounaris \& Gounaris, 2005).

The quality in the B2B is different whereby the customer is absent from the process component (Bienstock, Mentzer \& Bird, 1996). Instead of using the performance measurement perceived and expectation gap analysis or SERVQUAL, the model needs to follow the INDSERV and Gronroos (1984) model, which is based on the technical and functional factors (Durvasula, Lysonski \& Mehta, 1999), arising from its needs in the internal and external factors between two companies (Gounaris, 2005; Ladhari, 2008). The INDSERV model involves several dimensions such as the potential quality, hard process quality, soft process quality, and output quality as quoted from Lee (2010). In addition, the International/Industrial, Marketing and Purchasing Group (IMP) interaction model develops a quality model for B2B interaction (Ford \& Group, 1990; Gadde \& Hakansson, 2001). These factors are social exchange, cooperation financial exchange, information exchange and adaptation in the interaction model (Rahayu \& Anggriawan, 2014). Table 1 summarizes all these models their usage and dimensions in relation to B2B quality. 
Table 1. Evaluation service quality model in a B2B environment

\begin{tabular}{|c|c|c|c|c|}
\hline $\begin{array}{c}\text { B2B service } \\
\text { quality model }\end{array}$ & $\begin{array}{l}\text { B2B service quality } \\
\text { dimensions }\end{array}$ & $\begin{array}{c}\text { Study outcome in B2B } \\
\text { context }\end{array}$ & $\begin{array}{l}\text { This research } \\
\text { consideration }\end{array}$ & References \\
\hline $\begin{array}{l}\text { SERVQUAL } \\
\text { model }\end{array}$ & $\begin{array}{l}\text { "Reliability, availability, } \\
\text { ease of use, assurance, } \\
\text { timeliness, tangible, } \\
\text { empathy" }\end{array}$ & $\begin{array}{l}\text { Timeliness, availability } \\
\text { most significant factor for } \\
\text { quality of professional } \\
\text { buyers. }\end{array}$ & $\begin{array}{l}\text { Study Reliability, } \\
\text { Timeliness, availability as } \\
\text { quality factors E- } \\
\text { procurement } \\
\text { Implementation }\end{array}$ & $\begin{array}{l}\text { Bienstock et al., } \\
1996\end{array}$ \\
\hline $\begin{array}{l}\text { SERVQUAL } \\
\text { model }\end{array}$ & $\begin{array}{l}\text { "Tangibles, Service } \\
\text { Reliability, } \\
\text { Responsiveness, } \\
\text { Assurance" }\end{array}$ & $\begin{array}{l}\text { The predictive quality of } \\
\text { SERVQUAL in B2B } \\
\text { context was low. }\end{array}$ & Not applicable & $\begin{array}{l}\text { Brensinger \& } \\
\text { Lambert, } 1990\end{array}$ \\
\hline INDSERV model & $\begin{array}{l}\text { "Potential quality. Hard } \\
\text { Process quality, Soft } \\
\text { Process quality, Output } \\
\text { quality" }\end{array}$ & $\begin{array}{l}\text { INDSERV model better } \\
\text { predictors than } \\
\text { SERVQUAL model }\end{array}$ & $\begin{array}{l}\text { All factors apply in } \\
\text { quality model of this } \\
\text { research }\end{array}$ & $\begin{array}{l}\text { Durvasula et al., } \\
1999\end{array}$ \\
\hline $\begin{array}{l}\text { Gronroos (1984) } \\
\text { model }\end{array}$ & $\begin{array}{l}\text { "Technical and functional } \\
\text { quality" }\end{array}$ & $\begin{array}{l}\text { Very significant factor in } \\
\text { B2B context }\end{array}$ & $\begin{array}{l}\text { All factor applicable in } \\
\text { this research }\end{array}$ & $\begin{array}{l}\text { Patterson \& Spreng, } \\
1997\end{array}$ \\
\hline $\begin{array}{l}\text { Revised } \\
\text { SERVQUAL } \\
\text { model }\end{array}$ & $\begin{array}{l}\text { "Service reliability, } \\
\text { credibility, service } \\
\text { competence, intra- } \\
\text { organizational } \\
\text { communication, service } \\
\text { flexibility, financial trust } \\
\text { and pleasant } \\
\text { environment" }\end{array}$ & $\begin{array}{l}\text { All factors have } \\
\text { significant impact on } \\
\text { service quality perception } \\
\text { of professional buy ers. }\end{array}$ & $\begin{array}{l}\text { This factors all consider } \\
\text { as E-procurement } \\
\text { Implementation and } \\
\text { capability quality factors }\end{array}$ & $\begin{array}{l}\text { Seth, Deshmukh, \& } \\
\text { Vrat, } 2006\end{array}$ \\
\hline IMP model & $\begin{array}{l}\text { "Social exchange, } \\
\text { cooperation financial } \\
\text { exchange, product/ } \\
\text { service exchange, } \\
\text { information exchange, } \\
\text { and adaptation" }\end{array}$ & $\begin{array}{l}\text { Social exchange and } \\
\text { cooperation are relatively } \\
\text { more important than } \\
\text { others for evaluation of } \\
\text { quality for professional } \\
\text { services }\end{array}$ & $\begin{array}{l}\text { Social exchange and } \\
\text { cooperation use for } \\
\text { capability quality in E- } \\
\text { procurement }\end{array}$ & $\begin{array}{l}\text { Woo \& Ennew, } \\
2006\end{array}$ \\
\hline $\begin{array}{l}\text { 2B-RELPERF } \\
\text { scale model }\end{array}$ & $\begin{array}{l}\text { "Relationship policies } \\
\text { and practices, } \\
\text { Relationship } \\
\text { commitment, Trust in the } \\
\text { relationship, Mutual } \\
\text { cooperation" }\end{array}$ & $\begin{array}{l}\text { The buyer-supplier } \\
\text { relationship is the } \\
\text { knowledge sharing and } \\
\text { knowledge management } \\
\text { where organization move } \\
\text { to cooperation } \\
\text { Organizational culture }\end{array}$ & $\begin{array}{l}\text { All factors consider in } \\
\text { this quality model }\end{array}$ & $\begin{array}{l}\text { Badlani \& Paryani, } \\
\text { 2015; Foster, 2013; } \\
\text { Hussein et al., 2015; } \\
\text { Naudé et al., 2007; } \\
\text { Sun et al., 2014; } \\
\text { Tserpes et al., } 2008\end{array}$ \\
\hline
\end{tabular}

E-procurement implementation process has three categories, namely direct procurement, indirect procurement and sourcing (Gupta \& Browning, 2007). It comprises of four separate processes, namely supplier selection, making order, order fulfillment, and financial settlement and payment (Wright, 2002). Its implementation and process are system and technology, organization and management and practice and process (Caniato, Golini, Luzzini, \& Ronchi, 2010; Kaliannan, Awang \& Raman, 2009; Mahbubur, 2008; Roger \& Greylord 2003; Schotanus, Bakker, Walker \& Essig, 2011; Vaidya, Callender, Sajeev \& Gao, 2004).

Quality model of implementation of the E-procurement is translated into two dimensions quality model by Grönroos (1984) and INDSERV model. Firstly, system and technology potentially can be integrated with the old or new initiatives technologies in adopting e-business (Caniato et al., 2010; Kaliannan et al., 2009; Lee \& Whang, 2001; Mahbubur, 2008; William \& Presutti, 2003). Therefore, the quality of system technology is equal to the potential quality of E-procurement. Secondly, organization and management are required soft skills to manage the purchasing process (Brandon-Jones, 2009; Cagnazzo, Taticchi, Bidini \& Sameh, 2009;Filos, 2006; Walker \& Harland, 2008). Consequently, the quality in organization and management is covered in the soft quality in INDSERV model. The practice and process include exchange of information and material process (Harrigan, Boyd, Ramsey, Ibbotson \& Bright, 2008;Jahnukainen \& Lahti, 1999; Vaidyanathan \& Devaraj, 2008). Quality in the practice and process are the hard qualities in the INDSERV model. Besides, E-procurement success is an outcome quality model of this 
research. Hence, this model studies the relationship between the E-procurement capabilities (quality) in potential, soft, hard and outcome quality of E-procurement. This relationship is explained by Dynamic Capability Theory (DCT).

DCT is the ability to integrate, construct and re-arrange organizational internal and external factors as a core competencies, in order to adapt to the dynamic and ever changing environment (Teece, Pisano, \& Shuen, 1997). Dynamic capabilities are some general internal processes of organizations or routines which have been embedded into the firms' processes or routines (Helfat et al., 2009; Maritan \& Peteraf, 2007; Zollo \& Winter, 2002), which is shown in figure 1.

Figure 1. Summary of DCT definition ( modified Barney \& Mackey, 2005)

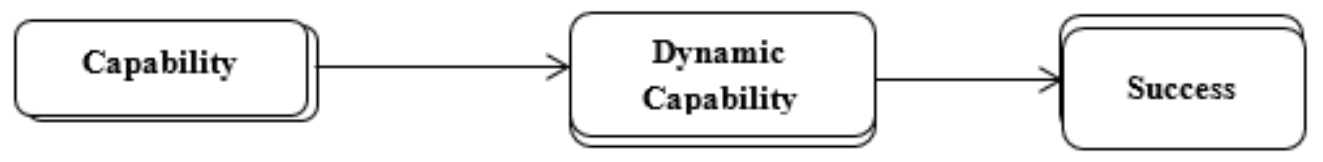

However, having considered this definition, it can be found that the focus of DC Theory is on the organization itself and the possible capabilities, which are located outside the company's boundaries, are neglected while there is a connection between IT investment and dynamic capabilities (Rai, Patnayakuni, \& Seth, 2006). The aforementioned integration can be categorized into two different domains, namely SC process integration and SC-related IT integration (Malhotra, Gosain, \& Sawy, 2005; Rai et. al., 2006; Wang, Tai \& Wei, 2006). The higher level of integration in a supply chain system leads to greater knowledge capability in the organization (Malhotra et al., 2005). However, the integration between the supply chain processes can only happen when an appropriate IT platform is available (Rai et. al., 2006). The current study in the supply chain management and E-procurement uses DCT as summarized in table 2. The capability effect on the process and its routine are based on DCT. Therefore, the relationship of capability and success affects the quality of E-procurement implementation. The conceptual framework of this paper is presented in figure 2, with below hypothesizes:

H1: Quality in system and technology, quality in organization and management, quality in practice and process mediate the relationship between quality in organizational culture and E-procurement success.

H2: Quality in system and technology, quality in organization and management, quality in practice and process mediate the relationship between quality in IT-Infrastructure and E-procurement success.

H3: Quality in system and technology, quality in organization and management, quality in practice and process mediate the relationship between quality in Knowledge Management Capability and E-procurement success.

Table 2. Current studies in supply chain management and E-procurement by DCT

\begin{tabular}{|c|c|c|c|}
\hline \multirow{5}{*}{$\begin{array}{c}\text { Dynamic } \\
\text { Capability } \\
\text { Theory }\end{array}$} & Purpose & Capability & Reference \\
\hline & CRM development & Marketing capability & Maklan \& Knox, 2009 \\
\hline & Financial performance & $\begin{array}{l}\text { Strategic group (SG) and product life cycle } \\
\text { (PLC). }\end{array}$ & Chiou, 2011 \\
\hline & Performance & E-business capabilities, Inter e-Business & Zhao, Lu \& Liu, 2010 \\
\hline & Company success & $\begin{array}{l}\text { Purchasing, Manufacturing, Sales and } \\
\text { Marketing, Performance management }\end{array}$ & Molnár1 et al., 2011 \\
\hline
\end{tabular}


Figure 2. Framework for E-procurement implementation success

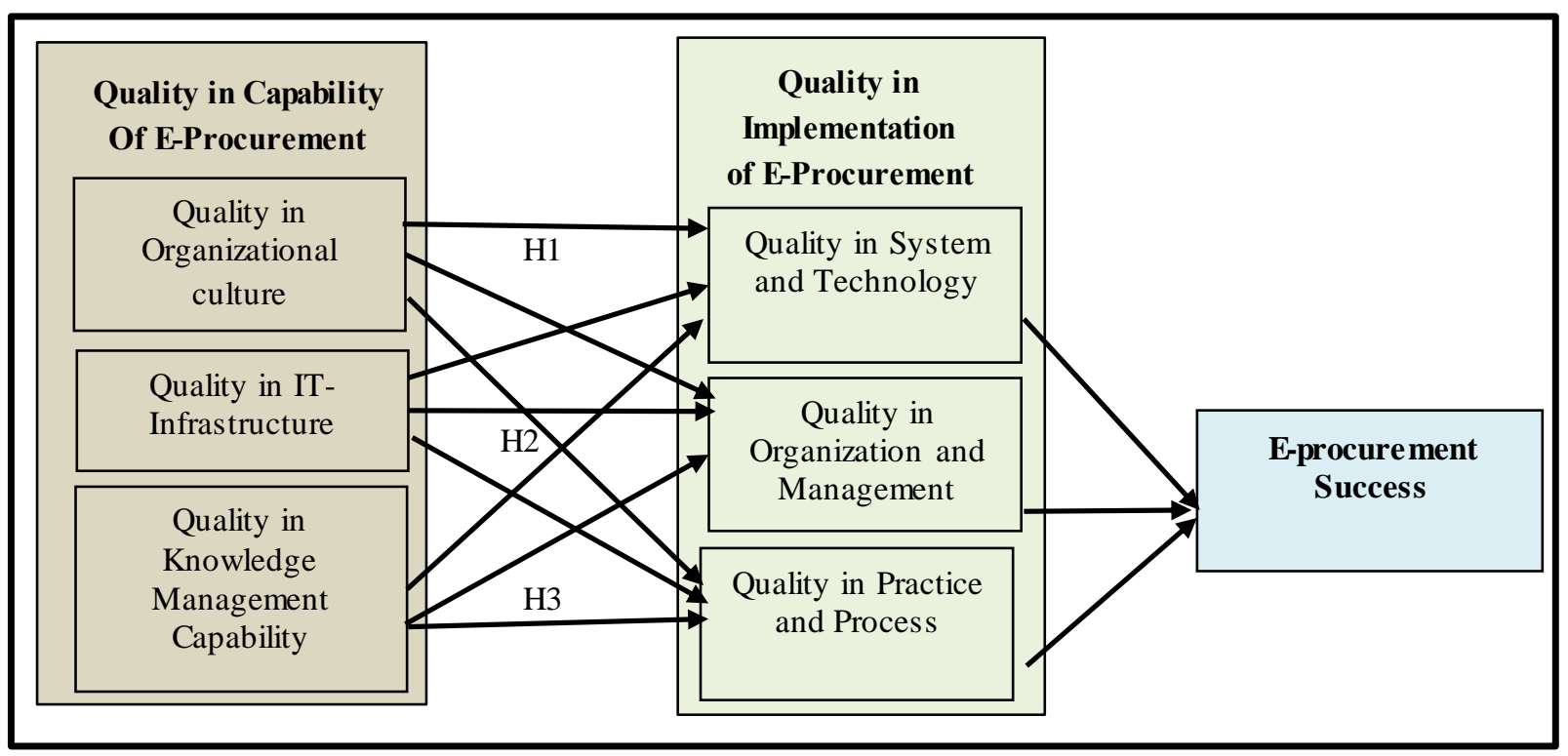

\section{Quality in E-Procurement Success Capabilities}

An E-procurement capability is needed to prepare the organization to adopt and deploy the new service or electronic service (Perera, Eadie, Heaney, \& Carlisle, 2006). E-procurement initiatives are the capability for E-procurement adoption (Vaidya et al., 2004). The first capability, organizational culture, and part of the strategic quality development factors are also important in the E-procurement improvement (Ashnai, 2006). Quality of organizational culture is defined as removing the roadblock to improvement, change and cooperate relationship in B2B context (Lee \& Gregory, 2010). A positive intention to adopt new systems in organizations could make organizations flexible (Chow et al., 2008).

Flexibility helps both sides of the trades, i.e. buyers and sellers, to form integration between their systems. The organization culture that promotes innovation and development can be evaluated by the entrepreneur organization factors such as flexibility level and innovation and creativity level (Hussein et al., 2015; Luftman \& Kempaiah, 2008). It is improving the supply chain, sub-suppliers, and their network; all of which need cooperate culture capability (Leirmo, 2013). Co-operation includes compatibility of mutual goals, inter-firm communication, participative decision making, ideological agreement and the use of power in a non-pressurized fashion. Quality in cooperation needs detailed communication, mutual respect, trust, teamwork through IT facility, which is more effective (Hussein et al., 2015). Quality perspective of IT infrastructure comprises of the software, hardware, network equipment and data form and format exchange data and the EDI technological performance (Bailey \& Jibril, 2006).

Better quality in communication and data or money exchange related to the standard format helps partners to face less difficulty in accessing to the related information (Brandon-Jones \& Carey, 2011 ; Eadie, Perera, \& Heaney, 2010; Hawking \& Stein, 2002; Kaliannan et al., 2009; Yu-hui, 2008). Since there is a payment section in the process of E-procurement systems, the issue of security is an important factor for both sides of the trade, sellers and buyers (Eadie et al., 2010). Besides, communication differentiation makes it very convenient for customer and partner to exchange information and money (Eadie et al., 2010). In addition, without knowledgeable employee ( IT expertise) to update and ensure the maintenance of the IT-infrastructure will not be affected from the IT benefits (Athanasopoulou, 2009). One of the requirements in the success of procurement and supply chain is the ability for knowledge sharing and capability in a mature relationship between the buyer and seller. Quality perspective of knowledge management capability is leveraged on the flow of knowledge inside the company. On the other hand, since SCM is a multi-player initiative, and is deployed between two or more companies, knowledge management helps the technology transfer between partners and is able to integrate the whole game (Chow, Choy, \& Lee, 2007) 
Quality perspective of knowledge management capability earns importance while the issues of sufficient knowledge, education and training in both buyers and sellers come through. This knowledge would be about content management, relationship management, e-tendering, e-marketplace, e-auction/ reverse auction, e-categories/ purchasing, and e-invoicing thus making the trust and transparency while knowledge capability includes Knowledge acquisition, knowledge application and knowledge sharing (Ashnai, 2006; Athanasopoulou, 2009; Badlani \& Paryani, 2015; Gounaris, 2005; Gounaris \& Gounaris, 2005; Hussein et al., 2015). Quality perspective of knowledge management capability can produce better performance (Shirzad \& Bell, 2013). The different dimensions of quality perspective of knowledge management capability include acquisition, conversion, application, and protection (Hsu, 2012).Quality perspective of knowledge management capability is based on the knowledge-based theories such as Knowledge Acquisition, Knowledge Application and Knowledge Sharing (Azadegan \& Ashenbaum, 2009; Jutla, Craig, \& Bodorik, 2001). Quality perspective of knowledge management capability serves to create knowledge and convert the tacit knowledge to explicit knowledge.

\section{Quality in Implementation of E-Procurement}

Successful implement of E-procurement steps (system and technology, organization and management, practice and process) are vital to increase the efficiency and effectiveness of E-procurement system. The quality in the system and technology is related to the compatibility and integration of characteristics of the old and new technologies (Caniato et al., 2010; Kaliannan et al., 2009; Lee \& Whang, 2001; Mahbubur, 2008; Vaidya, Sajeev, \& Callender, 2006; William \& Presutti 2003). The integrity of IT-infrastructure such as financial system, MIS system, IS system with an E-procurement system which will result in better and smooth electronic situations with less problem and higher quality (Koorn, Smith, \& Mueller, 2001; Leipold, Klemow, Holloway, \& Vaidya, 2004 ). Besides, these are needed to be reliable to lessen the cost of procurement system (Caniato et al., 2010; Kaliannan et al., 2009; Mahbubur, 2008).

Service reliability one of the SERVQUAL scale which is means making promises (Hussein et al., 2015). Electronic B2B service reliability refers to consistent, timely, dependable and unfailing service delivery (Patterson \& Spreng, 1997). Besides service delivery reliability, another factor of E-service quality is the service availability (Seth et al., 2006). Available technical opportunities involve social influencing process. Various teams with specific expertise, different leadership styles, strategic human resource management initiatives and efficiencies and effectiveness of planning, organization and control of management of purchasing procedures have an impact on the quality action of the E-procurement process (Brandon-Jones \& Carey, 2011 ; Cagnazzo et al., 2009; Filos, 2006; Walker \& Harland, 2008). From efficiency, it can be translated into reduction of error in decision making when ordering and inventory management as well as supplier selection.

Furthermore, the learning level in the organization of the E-procurement department is considered as an efficiency of E-procurement when the capacity and scheduling the logistics planning is an efficient investment for implementing a productive E-procurement system (Brandon-Jones, 2009; Millson, 2014; Vaidya et al., 2004). Moreover, in order to achieve the predetermined objectives of an E-procurement system, it should be designed and developed as a customer-oriented system. Indeed, any management system or technological hardware that, in any senses, cannot help the organization to create value for its customers is not align with the strategic maturity of performance of the organization (Woo \& Ennew, 2006). Efficiency refers to three important aspects corresponding to accessibility and system availability, usability and design, with excellent result and financial performance or profitability. The implementation of an E-procurement system comprises of several processes and operational activities. These practices and processes include the capacity management of raw material, order placement, order tracking and product delivery. Basically, the outcome of these activities will be evaluated by customers based on two measures, namely accuracy (Harrigan et al., 2008; Jahnukainen \& Lahti, 1999; Vaidyanathan \& Devaraj, 2008) and the timeliness of processes and activities (Hawking \& Stein, 2002; Vaidyanathan \& Devaraj, 2008).

Accuracy in E-procurement implementation process refers to the preciseness of activities which some of them were mentioned earlier (i.e. order placement etc.). For instance, if the accuracy of a raw material in the operational process or a part of that is not compatible with the basic standards, assuming all the other processes of Eprocurement are correct, a product is produced without being able to meet the customers' expectations. Another concern of E-procurement quality process is timeliness which relates to the on-time service delivery that needs to 
meet certain customer expectation. Furthermore, recognizing the competencies of special possessions, taking advantage of possible changes in the supply chain and E-procurement configuration(Harrigan et al., 2008). Configuration, is an ability to have transparency and vision of having a non-testable procedure, in order to have conformity between strategy and activity (Vaidyanathan \& Devaraj, 2008). Besides, standard legislation and function can cause internal and external awareness (Harrigan et al., 2008).

\section{RESEARCH METHODOLOGY}

Respondents included purchasing or procurement managers of manufacturing industries who are currently in -charge of deployment of the E-procurement and have outstanding involvement in the economic contribution and development. The manufacturing companies selected were based on the five years market share and economic report. Among 700 surveys issued, 220 accurate and reliable responses were available for analysis. This survey was distributed or carried out in meetings, and through email and telephone interview. To ensure the reliability of different groups of samples, the one-way ANNOVA was run on the data to make sure that the data variation is not significantly different. Therefore, there is no significant difference between the responding surveys. The cons istency of the latent variables was examined using the Cronbach alpha test which shows the minimum level of acceptance of coefficient is more than 0.7 .

Construct validity is a validity of measurement and the relationship between the factors which is tested by discriminate and convergent validity. Hence, the reliability of measurement analysis happens with the confirmatory factor analysis (CFA). As a result, the EFA test shows that factor loadings of latent variables are more than 0.5 . Besides, there is no significant correlation between the variables, as almost all the correlation is less than 0.7 . The adequacy of the sampling for all the variables measurement was tested using the Kaiser Meyer Olin (KMO) test that shows a value of more than 0.6 , which is acceptable. The convergent validity was tested using the EFA analysis through SPSS 20, in which the factor loading for variables are more than 0.5. Subsequently, the result of the EFA was moved to the AMOS 18 for CFA analysis and Hypotheses testing by (SEM) Structural Equation Modeling analysis. Model Estimation fit conducted using the Maximum Likelihood factors estimation (ML), the error term of factor measurement (Hoyle, 2012). All the model satisfied the requirements $\mathrm{X} 2 / \mathrm{DF}=\mathrm{a}=$ » $1<\mathrm{a}<5, \mathrm{P}$-value $=\mathrm{b}<$ 0.05 with $95 \%$ confidence level, $\mathrm{RMR}=\mathrm{c}<0.1$, PCLOSE $=\mathrm{d}<0.5$, CFI $=\mathrm{e}>0.9$, GFI $=\mathrm{f}>0.9$, AGFI $=\mathrm{f}>0.8$, $\mathrm{RFI}=\mathrm{g}>0.9, \mathrm{TLI}=\mathrm{h}>0.9, \mathrm{RMSEA}=\mathrm{k}<0.1$ and NFI $=\mathrm{n}>0.9$ (Loehlin, 2004).

\section{ANALYSIS AND RESULT}

Data analysis using the SEM model (Structural Equation Model) demonstrates the results and estimation of the structural model of this research as shown in figure 3. The indicators of fit model are satisfied with GFI of 0.99, which is more than 0.9 and AGFI of 0.849 , which is more than 0.8 . Other Indictors in this model has shown the fitness as table 3 .

Table 3. SEM model Estimation

\begin{tabular}{|c|c|c|c|c|c|c|c|}
\hline Chi- square $\chi^{2}$ & & 3.956 & & $=$ & $\mathrm{X} / \mathrm{DF}$ & \multirow{2}{*}{\multicolumn{2}{|c|}{$1<3.956<5$}} \\
\hline Df & & 1 & & $>$ & $X \angle / D F$ & & \\
\hline $\mathrm{P}$-value & \multicolumn{7}{|c|}{$0.047<0.05$ with $95 \%$ confidence level } \\
\hline RMR & \multicolumn{7}{|c|}{$0.005<0.1$} \\
\hline PCLOSE & \multicolumn{7}{|c|}{$.105<0.5$} \\
\hline CFI & $0.998>.9$ & RFI & $0.951>.9$ & TLI & $0.963>.9$ & NFI & $0.998>.9$ \\
\hline RMSEA & \multicolumn{7}{|c|}{$0.09 \leq 0.1$} \\
\hline
\end{tabular}

The Final model can satisfy the fit model requirement where it has RMSEA and RMR less than 0.1 and GFI, NFI, CFI all more than 0.9; therefore, the structure model is a good fit. This fit model proves how the structural relationship between these factors can cause success. It is proven how dy namic factors quality change the critical quality factors as a capability of E-procurement before causing the Final success and benefits of achievements by the dynamic capability theory. Common factor analysis during CFA analysis, there is not any issue in the data set and analys is is reliable. 
Organizational culture explains the behavior the components within the system to make reliable relationship. Besides, a significant portion of the initiative value proposition of IT infrastructure and Knowledge management capability have often not ultimately delivered due to problems related to technology, business process, people and organizational issues. The organizational culture is important to adopt the organization to new knowledge and changes to best practice and process development. Organization and management act as an efficient and effective toward the practice and process of advancing the knowledge management capability and IT infrastructure for smoothing the flow of the information and material where all stockholders adopt and flexible to changes. Therefore, the quality of the Organizational culture, knowledge management capability and IT infrastructure effectively on the Implementation of quality in E-procurement which is tested in the model figure 3.

In figure 3 all the indicators have standard regression weight above 0.6, which show that all three quality indicators for each factors explain and represent them for measurement. Innovation, flexibility, Co-operation representation of the quality factors of organizational culture, where communication channel capacity, security and authorization capability, besides IT expertise level and facility capacity is a good measurable indicator for IT infrastructure. Regarding knowledge management capability also knowledge acquisition, application, and sharing capability show the organizational power and quality in knowledge management it is because standard regression weight are above 0.6 .

Furthermore, the E- procurement implementation factors also has respective indicators for measurement which in the analysis shows they are satisfied requirement for measurement. Quality in System \& Technology present by level of capability of integration and compatibility, reliability and availability of system and technology. Where as, the quality in organization \& management evaluate based on efficiency, effectiveness and profitability of Eprocurement. And lastly, the quality in E-procurement practice and process measure by the Accuracy, timeliness and configuration of flow of the material and information.

Three main factors, namely total effect, direct and indirect effects have significantly explained the relationship of each quality in the capability of E-procurement success. Firstly, quality in Organizational culture shows direct significance of $0.002<0.05$, the indirect significance of $0.002<0.05$ and total effect of $0.048<0.05$, with 0.95 confidence interval. As a result, quality in 'system and technology', 'organization and management' and 'practice and process' serve as partial mediators of the quality in organizational culture and E-procurement success relationship. It means that, quality of both organizational culture and E-procurement success have a direct relationship with these mediators' qualities in organizational culture.

Secondly, the quality of IT- infrastructure and E-procurement success have a significant direct effect of 0.001 , the indirect effect is not significant with p-value.124>0.05, and the total effect of $0.002<0.05$. This shows that hypothesis two is rejected and IT- infrastructure has a direct effect on E-procurement success where it is also effected on a single element of E-procurement implementation. Therefore, quality in system and technology, organization and management, process and practice are not mediators in the E-procurement relationship with IT infrastructure.

Finally, the quality of the knowledge management capability and E-procurement success as third hypothesis is totally accepted. It is because the direct effect is not significant with $\mathrm{p}-$ value of $0.149>0.05$, indirect value of. $001<0.05$ and a significant total effect with. $001<0.05$. Therefore, the quality in 'system and technology', 'organization and management' and 'practice and process' are full mediators of quality in knowledge management capability and E-procurement success. This means, the quality in knowledge management through changing quality in E-procurement implementation factors can change the possibility of success of E-procurement. 
Figure 3: Research model Estimation

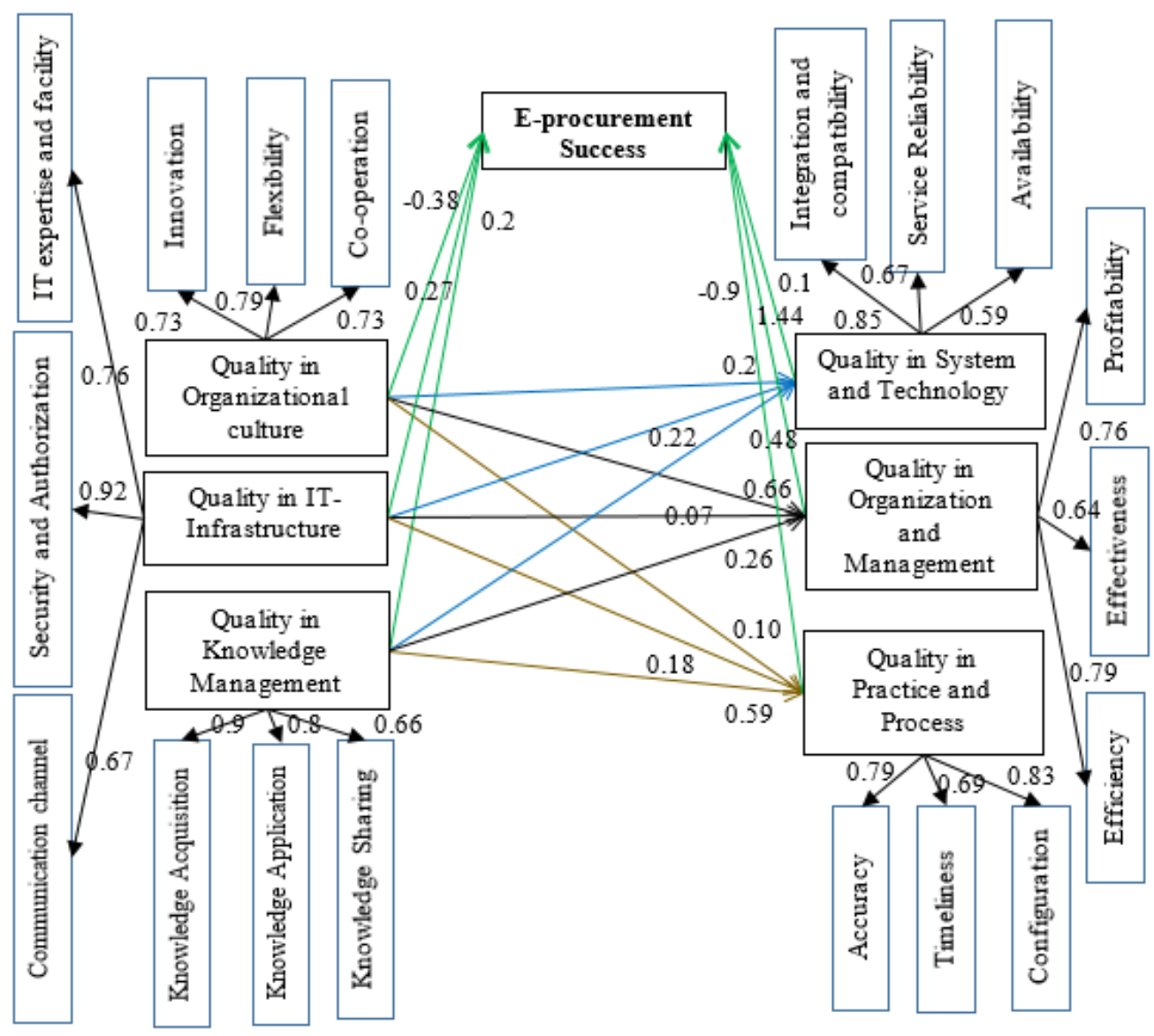

The results deliberate on the sustainability and steadiness of electronic procurement service, which are vital for B2B business to reduce costs and take advantage of its benefits. A lot of statistics in many countries show a high rate of loss of E-procurement. Total quality management (TQM) is one of the most valuable methods to reduce error and increase possible success. Hence, by introducing the quality factors of the E-procurement capability to support the quality in dynamic capability of an E-procurement implementation may result in better performance.

Furthermore, by commingling the quality models of B2B and DCT has introduced a new and specified quality Eprocurement model which explains the logical relationship between the factors. This model can be utilized not only to develop the B2B industry, but also to produce a better national economic environment with more successful businesses via the reduction of the inefficiency of B2B business and supply chain.

Regarding future research and recommendation, electronic service are one of the most common needs of the new industrial environment and economic growth. The international business need to adapt to the turbulence of the environment. This quality factor can be applied for global supply chain to improve the ability of successful implementation of e-procurement in the world. Hence, as a development of the e-procurement, continuous research should be done for strategic development to remove more barriers of e-procurement or for achieving more benefits of e-procurement. Further research is needed generalizing the findings of this research in different industries. Otherwise, future research also can happen by applying this framework in a different industry or service scope.

The other future research can focus on extending the model with more variables or different variables. It means that, Applying and extending this framework for more quality factors in e-procurement. Whereas, it can use the other theory that can be mixed with this research theory. Besides, it can use other quality model for an evaluation of the 
quality in e- procurement. Besides, it can identify the moderator factors or other mediators that effects on the relationship and significance of relationships of the model.

Lastly, this research can be recommended for comparing the companies who apply and do not apply the eprocurement, to evaluate the different perception regarding quality development of the E-procurement framework. Or by using other quality model and theories to evaluate the e-procurement success and compare with this research result.

\section{AUTHOR BIOGRAPHIES}

Mahnaz Eskandarian is a Ph.D. candidate of Graduate School of Management (GSM), Multimedia University, Cyberjaya Campus, Malaysia, she received her Bachelor of Industrial Management, Isfahan University of Iran, Iran, and Master of Business management, from Islamic Azad University Arak branch of Iran, Iran, and currently lecture of Department of Management, Payame Noor University, Tehran, Iran.

Professor Govindan Marthandan is the Deputy Dean (Academic) in Graduate School of Management Multimedia University, Malaysia. He received his Bachelor of Engineering, Master of Engineering and Ph.D. from University of Madras India and Master of Business Administration (Operations Management) from IGNOU, India. His wide area of interest includes Operations Management, Supply Chain Management, Quality, the Information System development, IS evaluation, ICT applications, Web data mining, E-commerce and Supply Chain Management. He is supervising many postgraduates for $\mathrm{PhD}$, DBA and MBA. He has a vast experience working with IT industry, government and academic institutions.

Dr. C. A. Malarvizhi is senior lecture of Faculty of Management in Multimedia University, Cyberjaya Campus, Malaysia and her research area is Economic.

Sanaz ZolfagharTehrani is the Communicating author, Lecture of Faculty of Management, California State university of California, Ph.D. candidate, Graduate School of Management (GSM), Multimedia University, Cyberjaya Campus; Master of Industrial Engineering, Science \& technology University of Iran, Iran, Bachelor of Industrial Engineering- Industrial Safety, labour University, related to labour and social Affairs ministry of Iran, Iran research Area: operation management, Lean manufacturing, optimization, decision making and IT management. For more communication you can contact with blow email addresses: szolfaghartehrani1@toromail.csudh.edu; 1081600013@student.mmu.edu.my or sanazindustrial@gmail.com

\section{REFERENCES}

Al-Awadhi, J. H. (2009). E-procurement in KNPC; Did it make a difference, Maastricht, the Netherlands, (Unpublished Master dissertation). Maastricht School of Management (MSM).

Ashnai, B. (2006). An analy sis of B2B relationship quality among Iranian Managers. Master thesis. (Master's thesis, Lulea University of Technology, Scandinavia, Sweden). Retrieved from: https://pure.ltu.se/portal/files/31012433/LTU-PBEX-0651-SE.pdf

Athanasopoulou, P. (2009). Relationship quality: a critical literature review and research agenda. European Journal of Marketing, 43(5/6), 583-610.

Azadegan, A., \& Ashenbaum, B. (2009). E-procurement in Services: The Lagging Application of Innovation. International Journal of Procurement Management 2(1), 25-40.

Badlani, M., \& Pary ani, P. (2015). Effectiveness of Bank Advertising in India-Recent Perceptions in Marketing of Services, INCON 2015 Journal_Marketing, No.51, 1-9

Bailey, M., \& Jibril , M. (2006). E-procurement Strategy(Report No.3). Retrieved from Breckland website: https://www.breckland.gov.uk/article/1782/Residents.

Barney, J. B., \& Mackey, T. B. (2005). Testing resource-based theory. Research methodology in strategy and management, 2, 113.

Bienstock, C. C., Mentzer, J. T., \& Bird, M. M. (1996). Measuring phy sical distribution service quality. Journal of the Academy of Marketing Science, 25(1), 31-44.

Brandon-Jones, \& A. and Carey, S. (2011). The impact of user-perceived E-procurement quality on sy stem and contract compliance. International Journal of Operations \& Production Management, 31(3), 274-296. 
Brandon-Jones, A. (2009). Improving E-procurement compliance: The role of user perceptions. Paper presented at the POMS 20th Annual Conference, Orlando, Florida, USA.

Brensinger, R. P., \& Lambert, D. M.(1990). Can the SERVQUAL scale be generalized to business-to-business services? Knowledge Development in Marketing, 289.

Burgess, L. (2014). A conceptual model of B2B online service quality.

Cagnazzo, L., Taticchi, P., Bidini, G., \& Sameh, M. (2009). Collaborative procurement within enterprise networks: a literature review, a reference framework and a case study. In Leveraging Knowledge for Innovation in Collaborative Networks (pp. 351-360). Springer Berlin Heidelberg.

Caniato, F., Golini, R., Luzzini, D., \& Ronchi, S. (2010). Towards full integration: eProcurement implementation stages. Benchmarking: An International Journal, 17(4), 491-515.

Chiou, C. H. (2011). Dy namic capabilities, collaborative network and business model: an empirical analy sis of Taiwan HTC Corporation. African Journal of Business Management, 5(2), 294. http://www.academicjournals.org/AJBM, 5(2), 294305. doi: $10.5897 / A J B M 09.440$

Chi, M., Zhao, J., Lu, Z., \& Liu, Z. (2010). Analy sis of E-business capabilities and performance: From e-SCM process view. In Computer Science and Information Technology (ICCSIT), 2010 3rd IEEE International Conference on (Vol. 1, pp. 18-22). IEEE.

Chow, H. K., Choy, K. L., \& Lee, W. (2007). Knowledge management approach in build-to-order supply chains. Industrial Management \& Data Systems, 107(6), 882-919.

Chow, W. S., Madu, C. N., Kuei, C.-H., Lu, M.H., Lin, C., \& Tseng, H. (2008). Supply chain management in the US and Taiwan: An empirical study. Omega, 36(5), 665-679.

Durvasula, S., Ly sonski, S., \& Mehta, S. C. (1999). Testing the SERVQUAL scale in the business-to-business sector: The case of ocean freight shipping service. Journal of Services Marketing, 13(2), 132-150.

Eadie, R., Perera, S., \& Heaney, G. (2010). Identification of E-procurement drivers and barriers for UK construction organisations and ranking of these from the perspective of quantity survey ors. Journal of Information Technology in Construction, 15, 23-43.

Filos, E. (2006). Smart Organizations in the Digital Age In: Mezgár, I. (Ed.): Integration of Information and Communication Technologies in Smart Organizations.Idea Group Publishing, Hershey, 1-38.

Ford, D., \& Group, I. (1990). Understanding business markets: Interaction, relationships and networks: Academic Press London.

Foster, S. T. (2013). Managing Quality: Integrating the Supply Chain: International Edition: Pearson Education Limited.

Gadde, L., \& Hakansson, H. (2001). Supply Chain Network Strategies: John Wiley \& Sons, Chichester.

Goetsch, D. L., \& Davis, S. B. (2014). Quality management for organizational excellence: pearson.

Gounaris, S. (2005). An alternative measure for assessing perceived quality of software house services. The Service Industries Journal, 25(6), 803-823. doi: 10.1080/02642060500103373

Gounaris, S., \& Gounaris, S. (2005). Measuring service quality in B2B services. an evaluation of the SERVQUAL scale vis-à-vis the INDSERV scale, 19(6), 421-435. doi: 10.1108/08876040510620193

Gupta, A., \& Browning, W. (2007). E-procurement: Trials and Triumphs. US, Aberdeen Group report. http://www.aberdeen.com/.

Harrigan, P. O., Boyd, M. M., Ramsey, E., Ibbotson, P., \& Bright, M. (2008). The development of E-procurement within the ICT manufacturing industry in Ireland. Management Decision, 46(3), 481-500.

Hawking, P., \& Stein, A. (2002). E-procurement Drivers and Barriers Association for Information Sy stems;AIS Electronic Library (AISeL), http://aisel.aisnet.org/acis2002/31 (Vol. 31).

Helfat, C. E., Finkelstein, S., Mitchell, W., Peteraf, M., Singh, H., Teece, D., \& Winter, S. G. (2009). Dynamic capabilities: Understanding strategic change in organizations: John Wiley \& Sons, Malden, MA, USA. Blackwell Publishing

Hsu, S.-H. (2012). Effects of Competitive Strategy, Knowledge Management and E-Business Adoption on Performance. The Journal of Human Resource and Adult Learning, 8(2).

Hussein, A., Hassan, M., \& Hamid, M. A. K. A. (2015). Factors affecting retail b2b relationship quality in Egy pt. The Business \& Management Review, 6(1), 166.

Jahnukainen, J., \& Lahti, M. (1999). Efficient purchasing in make-toorder supply chains. International Journal of Production Economics, 59, 103-111.

J Jutla, D., Craig, J., \& Bodorik, P. (2001). Enabling and measuring electronic customer relationship management readiness. In Sy stem Sciences, 2001. Proceedings of the 34th Annual Hawaii International Conference on (pp. 10-pp). IEEE.

Kajan, E. (2012). Handbook of Research on E-Business Standards and Protocols: Documents, Data and Advanced Web Technologies: Documents, Data and Advanced Web Technologies: Business Science Reference.

Kaliannan, O. M., Awang, H., \& Raman, M. (2009). Government purchasing: A review of E-procurement system in Malay sia. Bilgi Ekonomisi ve Yönetimi Dergisi, 4(1).

Koorn, R., Smith, D., \& Mueller, C. (2001). E-procurement and Online Marketplaces. Amsterdam, The Netherlands: Compact.

Kothari, T., Hu, C., \& Roehl, W. S. (2005). E-procurement: an emerging tool for the hotel supply chain management. International Journal of Hospitality Management, 24(3), 369-389.

Ladhari, R. (2008). Alternative measures of service quality: a review. Managing Service Quality: An International Journal, 18(1), 65-86. 
Lattimore, O. (2001). Electronic commerce tools that address supply chain performance. V. 35, No. 4 P. 11-12: ILL. Logistics Spectrum.

Lee, \& Gregory, J. (2010). Employee Flow as an Integrated and Qualitative Sy stem: Impact on Business-to-Business Service Quality. Journal of Business-to-Business Marketing, 17(1), 1-28. doi: 10.1080/10517120903000348

Lee, H. L., \& Whang, S. (2001). Winning the last mile of e-commerce. MIT Sloan Management Review, 42(4), 54.

Leipold, K., Klemow, J., Holloway, F., \& Vaidya, K. (2004). The world bank E-procurement for the selection of consultants: Challenges and lessons learned. Journal of Public Procurement, 4(3), 319-340.

Leirmo, M. G. (2013). Improving regional supplier - sub supplier network. (Master of Science in Maritime Management ), Høgskolen i Vestfold. Retrieved from http://hdl.handle.net/11250/191783

Loehlin, J. C. (2004). Latent variable models: An introduction to factor, path, and structural equation analy sis: Psychology Press.

Luftman, J., \& Kempaiah, R. (2008). An Update on Business-IT Alignment: “A Line” Has Been Drawn. MIS Quarterly 6(3), $165-117$.

Malhotra, A., Gosain, S., \& Sawy, O. A. E. (2005). Absorptive capacity configurations in supply chains: gearing for partnerenabled market knowledge creation. MIS quarterly, 145-187.

Maritan, C., \& Peteraf, M. (2007). Dynamic capabilities and organizational processes. Dynamic capabilities: understanding strategic change in organizations, 30-45.

Mentzer, J. T., DeWitt, W., Keebler, J. S., Min, S., Nix, N. W., Smith, C. D., \& Zacharia, Z. G. (2001). Defining supply chain management. Journal of Business logistics, 22(2), 1-25.

Millson, M.R. (2014). Exploring the dimensions of product quality: implications for marketing and R\&D management. International Journal of Technology Intelligence and Planning, 10(2), 87-107.

Molnar, A., Kühne, B., Miroslav, B., András, S., Attila, P., \& Gellynck, X. (2011). Supply chain competences: the case of the traditional food sector in the EU. In 5th International European forum on Sy stem Dy namics and Innovation in Food Networks ((IGLS-Forum).

Naudé, P., Ashnai, B., Chaharsooghi, K., \& Perzon, H. (2007). An analy sis of B2B relationship quality among Iranian managers: A comparison between Iranian and English managers. Total Quality Management \& Business Excellence, 18(8), 861874.

Patterson, P. G., \& Spreng, R. A. (1997). Modelling the relationship between perceived value, satisfaction and repurchase intentions in a business-to-business, services context: an empirical examination. International Journal of service Industry management, 8(5), 414-434.

Perera, S., Eadie, R., Heaney, G., \& Carlisle, J. (2006). Developing a model for the analy sis of E-procurement capability maturity of construction organisations. In The Proceedings Joint International Conference on Construction Culture, Innovation, and Management (CCIM), November (pp. 26-29).

Rahayu, N. W., \& Anggriawan, F. (2014). Evaluating Indonesian C2C and B2C quality using eQual: A preliminary research. In Electrical Engineering and Computer Science (ICEECS), 2014 International Conference on (pp. 163-167). IEEE.

Rahim, Md. Mahbubur. (2008). Identify ing factors affecting acceptance of E-procurement systems: An initial qualitative study at an Australian City Council. Communications of the IBIM A, 3(1), 7-17.

Rai, A., Patnay akuni, R., \& Seth, N. (2006). Firm performance impacts of digitally enabled supply chain integration capabilit ies. MIS quarterly, 225-246.

Robaty Shirzad, s., \& Bell, D. (2013). A sy stematic literature review of flexible E-procurement marketplace. Journal of theoretical and applied electronic commerce research, 8(2), 49-70.

Roger, L. M., \& Greylord, J. (2003). Measuring and Improving Value of E-procurement Initiatives. University of WisconsinMadison, USA: Consortium for Global Electronic Commerce(CGEC).

Schotanus, F., Bakker, E., Walker, H., \& Essig, M. (2011). Development of purchasing groups during their life cycle: from infancy to maturity. Public Administration Review, 71(2), 265-275.

Segarra-Moliner, J.-R., Moliner-Tena, M.-A., \& Sánchez-Garcia, J. (2013). Relationship quality in business to business: a crosscultural perspective from universities. Marketing Intelligence \& Planning, 31(3), 196-215

Seth, N., Deshmukh, S., \& Vrat, P. (2006). A framew ork for measurement of quality of service in supply chains. Supply Chain Management: An International Journal, 11(1), 82-94.

Stan Maklan, \& Simon Knox. (2009). Dynamic Capabilities: the missing link in CRM investments. European Journal of Marketing, 43(11/12), 1392-1410.

Su, Q., Song, Y.-t., Li, Z., \& Dang, J.-x. (2008). The impact of supply chain relationship quality on cooperative strategy. Journal of Purchasing and Supply Management, 14(4), 263-272. doi: http://dx.doi.org/10.1016/j.pursup.2008.08.002

Sun, P.-C., Pan, F.-T., Wu, P.-C., \& Kuo, C.-C. (2014). An Empirical Study of B2B Relationship Value-Offering Type As a Moderator. Journal of Business Studies Quarterly, 6(1).

Teece, D. J., Pisano, G., \& Shuen, A. (1997). Dy namic capabilities and strategic management. Strategic management journal, 18(7), 509-533.

Teo, T. S., Lin, S., \& Lai, K.-h. (2009). Adopters and non-adopters of E-procurement in Singapore: An empirical study. Omega, 37(5), 972-987. 
Tserpes, K., Kyriazis, D., Meny chtas, A., Litke, A., Christogiannis, C., \& Varvarigou, T. (2008). Evaluating quality provisioning levels in service oriented business environments. In Enterprise Distributed Object Computing Conference, 2008. EDOC'08. 12th International IEEE (pp. 309-315). IEEE.

Vaidya, K., Callender, G., Sajeev, A., \& Gao, J. (2004). Towards a model for measuring the performance of E-procurement initiatives in the Australian public sector: a balanced scorecard approach. Paper presented at the Australian eGovernance Conference, April.

Vaidy a, K., Sajeev, A. S. M., \& Callender, G. (2006). Critical Factors That Influence E-procurement Implementation Success in the Public Sector. Journal of Public Procurement, 6(1\&3), 70-99.

Vaidy anathan, G., \& Devaraj, S. (2008). The role of quality in E-procurement performance: An empirical analy sis. Journal of Operations Management, 26(3), 407-425.

Vaidy anathan, G., \& Devaraj, S. (2008). The role of quality in E-procurement performance: An empirical analy sis. . ournal of Operations Management, J(26), 407-425. doi: doi:10.1016/j.ijinfomgt.2006.03.010

Van Aerschot, S. (2007). Onderzoek naar klantentevredenheid in B2B: toepassingen en nieuwe evoluties.

W. S. Chow, C. N. Madu, C-H. Kuei, M., H. Lu, C. L., \& Tseng., H. (2007). Supply chain management in the US and Taiwan: an empirical study. Int. J. Manag. Sci, 36, 665-679.

Walker, H., \& Harland, C. (2008). E-procurement in the United Nations: influences, issues and impact. International Journal of Operations \& Production Management, 28(9), 831 - 857.

Wang, E. T., Tai, J. C., \& Wei, H.-L. (2006). A virtual integration theory of improved supply-chain performance. Journal of Management Information Sy stems, 23(2), 41-64.

William, D., \& Presutti, J. (2003). Supply management and E-procurement: creating value added in the supply chain. Industrial Marketing Management, 32, 219-226.

Woo, K.-s., \& Ennew, C. (2006). Measuring business-to-business professional service quality and its consequences. Quality control and applied statistics, 51(4), 445-446.

Wright, D. (2002). Comparative evaluation of electronic pay ment systems. INFOR, 40(1), 71.

Yu-Hui, L. (2008). An empirical investigation on the determinants of E-procurement adoption in Chinese manufacturing enterprises. In Management Science and Engineering, 2008. ICMSE 2008. 15th Annual Conference Proceedings. International Conference on (pp.32-37). IEEE.

Zollo, M., \& Winter, S. G. (2002). Deliberate learning and the evolution of dynamic capabilities. Organization science, 13(3), 339-351. 


\section{NOTES}

